\title{
PRODUCTION AND TRADING OF BIOMASS FOR ENERGY - AN OVERVIEW OF THE GLOBAL STATUS
}

\author{
Heinimö, J. ${ }^{1} \&$ Junginger, M. ${ }^{2}$ \\ ${ }^{(1}$ Department of Energy and Environmental Technology, Lappeenranta University of Technology, \\ P.O. Box 181, 50101 Mikkeli, Finland, E-mail jussi.heinimo@lut.fi \\ ${ }^{2}$ Copernicus Institute, Utrecht University, Van Unnikgebouw, Heidelberglaan 2, 3584 CS Utrecht, the Netherlands, \\ E-mail M.Junginger@chem.uu.nl
}

\begin{abstract}
Biomass is becoming a more attractive source of renewable energy and the markets of solid and liquid biofuels are developing rapidly. Determining the international traded biomass volumes that end up in energy use is difficult for several reasons, such as challenges regarding the compilation of statistics on the topic. While for some markets (pellets, ethanol) separate overviews exist, no comprehensive statistics and summaries aggregating separate biomass streams are available. The aim of this paper was to review the challenges related to measuring internationally traded volumes of biofuels and to summarise the trade volumes of various biofuels. The scope of international biofuels trade was estimated in 2004 to be about 0.8 EJ. Indirect trade of biofuels thorough trading of industrial round wood and material byproducts comprises the largest part of trading having a share of about 0.5 EJ. The remaining part of trading consisted of products that are traded primarily for energy purposes, ethanol (0.09 EJ) and palm oil (0.04 EJ) being the most important articles. Compared to current global energy use of biomass (43 $\mathrm{EJ} / \mathrm{yr}$ ) and to the long-term theoretical trading potential between the world regions (80-150 EJ/yr), the development of the international trade of biomass for energy purposes is in its initial stage.
\end{abstract}

Keywords: biomass trade, biomass resources, biomass production

\section{INTRODUCTION}

Increasing oil prices, commitment to decrease greenhouse gas emissions and securing and diversifying the supply of energy are rendering various biomass types more interesting fuels in industrialised countries, and the modern use of biomass is increasing rapidly in many parts of the world. Fulfilling the growing demand, biomass has to be transported longer distances and even imported from other continents. This trade is currently in its initial phases, wood pellets, ethanol and palm oil being typical examples. However, good statistics on the global international trade in biofuels are not available. While for some markets (pellets, ethanol) separate overviews exist, no comprehensive overview is available on global biomass trade. Yet, such an overview is deemed highly relevant for market actors and policy makers.

Determining international traded biofuel volumes is difficult for several reasons. First of all, many biomass streams are traded for material purposes, but they finally end up in energy production. Second, biomass streams can have several final applications, for example palm oil (feedstock for bio-diesel or for food applications) or ethanol (as transportation fuel or as feedstock for the chemical industry). Third, some biomass fuels such as wood pellets and bio-ETBE are recorded in aggregated form by foreign trade statistics. E.g. wood pellets are recorded under the same code with wood waste in the EU's trade statistics, thus making it difficult to asses the volume.

The main aim of this paper is to summarise the current status of international biofuels trade presented by several separate sources. The structure of the paper is as follows: In the beginning the present role and long term opportunities of biomass in the global energy supply are reviewed. Subsequently, the scale of international biofuels trade by type of biofuels is identified. Following that, global trade streams of the most important biofuels are highlighted.

\section{THE ROLE OF BIOMASS IN THE WORLD'S ENERGY SUPPLY}

Fossil fuels - oil, coal and natural gas - dominate the world energy economy covering nearly $80 \%$ of the world's primary energy supply of 433 EJ (Table I). Renewable energy sources ${ }^{1}$ accounted for $14 \%$ (59 EJ) of the world's total primary energy demand in 2002. Biomass $^{2}$ is by far the largest source of renewable energy. Over two thirds (32 EJ) of biomass is used for cooking and heating in developing countries. The remaining $15 \mathrm{EJ}$ of the energy use of biomass takes place in industrialised countries where biomass is utilised both in industrial applications within the heat, power and road transportation sectors and in the heating purposes of the private sector. [1]

Table I: World primary energy demand in 2002 [1]

\begin{tabular}{lrr}
\hline Source of energy & [EJ] & Proportion \\
\hline Coal & 100 & $23 \%$ \\
Oil & 154 & $36 \%$ \\
Gas & 92 & $21 \%$ \\
Nuclear & 29 & $7 \%$ \\
Hydro & 9 & $2 \%$ \\
Biomass and waste & 47 & $11 \%$ \\
Other renewables & 2 & $1 \%$ \\
In total & 433 & $100 \%$ \\
\hline
\end{tabular}

Generally, biomass has been a marginal source of energy in industry and district heating. However, in countries such as Sweden, Finland and Austria, which have a large forestry sector, forest-based biomass has a

\footnotetext{
${ }^{1}$ Refers to renewable non-fossil sources of energy (wind, solar, geothermal, wave, tidal, hydropower, biomass, landfill gas, sewage treatment plant gas and biogas).

${ }^{2}$ Refers to the biodegradable fraction of products, wastes and residues from agriculture (including vegetal and animal substances) and forestry and related industries, as well as the biodegradable fraction of industrial and municipal waste.
} 
remarkable importance. E.g. in Finland, renewable energy sources cover $25 \%$ of the total primary energy consumption, and over $80 \%$ of renewable energy was derived from wood [2].

Biomass fuels approximately $1 \%$ of global electricity production, and it is often used in combined heat and power production (CHP) [1]. The global biomass power generation capacity is approximately $39 \mathrm{GW}$ [3]. The global consumption of liquid biofuels in transportation was 0.33 EJ in 2002, of which Brazil accounted for $70 \%$ and the United States for $23 \%$. The share of biofuels in total global transport consumption was only $0.4 \%$ [1].

International climate agreements are the ultimate factor for the ongoing positive development of bioenergy. Most industrialised countries have committed themselves to a significant decrease in greenhouse gas emissions in the Kyoto Protocol. An important means of attaining this goal is increasing the share of renewable energy sources in the total energy supply. The EU, as an example, aims to double the use of biomass from the level of 2003 by 2010 [4]. This will mean a 3.4 EJ increase in the annual energy use in the union.

\section{LONG TERM BIOMASS PRODUCTION POTENTIAL FOR ENERGY PURPOSES}

Despite the current minor role of bioenergy, biomass has, in the long run, the potential to become a much more significant source of energy in the global energy supply. Numerous studies have been carried out to estimate the potential to harvest energy from biomass. A review of the 17 studies carried out by Berndes et al. in 2002 revealed that the studies gave widely differing estimates of the contribution of biomass; from below $100 \mathrm{EJ} / \mathrm{yr}$ to above $400 \mathrm{EJ} / \mathrm{yr}$ in 2050 in the global energy supply [5]. Nevertheless, it was clarified that the largest biomass production potential will be in large-scale energy plantations that are located in areas having a favourable climate for maximising the production of biomass. The major reason for the differences between the results of the studies is that the most crucial parameters - land availability and yield levels in energy crop production are very uncertain, and subject to widely different opinions and assumptions for underlying scenarios.

Later on, several new studies have been addressed to the issue [see e.g. 6, 7, 8]. In the most optimistic scenarios, bioenergy provides for more than the current global energy demand, without competing with wood production, forest production and biodiversity. Table II gives a summary of the biomass production potential in the light of the latest studies by biomass categories and shows the main assumptions made in the determination of the potentials. Latin America, Sub-Saharan Africa and Eastern Europe as well as Oceania and East and NorthEast Asia have the most promising potential to become important biomass producers in the long run [9].

Table II: Overview of the global potential bioenergy supply on the long term for a number of categories and the main preconditions and assumptions that determine these potentials [9]

\begin{tabular}{|c|c|c|}
\hline Biomass category & Main assumptions and remarks & $\begin{array}{l}\text { Potential bioenergy supply } \\
\text { up to } 2050,[\mathrm{EJ} / \mathrm{yr}]\end{array}$ \\
\hline $\begin{array}{l}\text { Energy farming on } \\
\text { current agricultural } \\
\text { land }\end{array}$ & $\begin{array}{l}\text { Potential land surplus: } 0-4 \text { Gha (more average: } 1-2 \mathrm{Gha} \text { ). A large surplus } \\
\text { requires structural adaptation of intensive agricultural production systems. } \\
\text { When this is not feasible, the bioenergy potential could be reduced to zero, as } \\
\text { well. On an average, higher yields are likely because of better soil quality: } 8-12 \\
\text { dry tonne/ha*yr is assumed }{ }^{\text {(a }} \text {. }\end{array}$ & $\begin{array}{l}0-700 \\
\text { (more average development: } \\
100-300)\end{array}$ \\
\hline $\begin{array}{l}\text { Biomass production } \\
\text { on marginal lands }\end{array}$ & $\begin{array}{l}\text { On a global scale, a maximum land surface of } 1.7 \text { Gha could be involved. Low } \\
\text { productivity of } 2-5 \text { dry tonne/ha* } \text { yr }^{\text {(a }} \text {. The supply could be low or zero due to } \\
\text { poor economics or competition with food production. }\end{array}$ & (0) $60-150$ \\
\hline Bio-materials & $\begin{array}{l}\text { Range of the land area required to meet the additional global demand for bio- } \\
\text { materials: } 0.2-0.8 \text { Gha. (Average productivity: } 5 \text { dry tonnes/ha*yr). This demand } \\
\text { should come from categories I and II in case the world's forests are unable to } \\
\text { meet the additional demand. If they are, however, the claim on (agricultural) } \\
\text { land could be zero. }\end{array}$ & $\begin{array}{l}\text { Minus } \\
\text { (0) } 40-150\end{array}$ \\
\hline $\begin{array}{l}\text { Residues from } \\
\text { agriculture }\end{array}$ & $\begin{array}{l}\text { Estimates from various studies. The potential depends on yield/product ratios } \\
\text { and the total agricultural land area as well as the type of production system: } \\
\text { Extensive production systems require re-use of residues for maintaining soil } \\
\text { fertility. Intensive systems allow for higher utilisation rates of residues. }\end{array}$ & $15-70$ \\
\hline Forest residues & $\begin{array}{l}\text { The (sustainable) energy potential of the world's forests is unclear. Part is } \\
\text { natural forest (reserves). The range is based on literature data. Low value: figure } \\
\text { for sustainable forest management. High value: technical potential. Figures } \\
\text { include processing residues. }\end{array}$ & (0) $30-150$ \\
\hline Dung & $\begin{array}{l}\text { Use of dried dung. Low estimate based on global current use. High estimate: } \\
\text { technical potential. Longer-term utilisation (collection) is uncertain. }\end{array}$ & (0) $5-55$ \\
\hline Organic wastes & $\begin{array}{l}\text { Estimate on basis of literature values. Strongly dependent on economic } \\
\text { development, consumption and use of bio-materials. Figures include the organic } \\
\text { fraction of municipal solid waste (MSW) and waste wood. Higher values } \\
\text { possible by more intensive use of bio-materials. }\end{array}$ & $5-50(+)^{(b}$ \\
\hline Total & $\begin{array}{l}\text { Most pessimistic scenario: no land available for energy farming; only utilisation } \\
\text { of residues. Most optimistic scenario: intensive agriculture concentrated on } \\
\text { better quality soils. (in brackets: more average potential in a world aiming for } \\
\text { large scale utilisation of bioenergy) }\end{array}$ & $\begin{array}{l}40-1100 \\
(250-500)\end{array}$ \\
\hline
\end{tabular}




\section{INTERNATIONAL TRADE OF BIOMASS FOR ENERGY PURPOSES}

4.1. Interconnection between trade streams of biomass and biofuels

A significant number of cross-border streams that include biomass in diverse forms can be found. These streams of biomass - raw, processed or within products together with their various end-use purposes constitute a complex field which is simply outlined in Figure 1.

Imported biomass or a product that includes biomass can be processed in the import country into more refined final products, which are then consumed in the country or exported forward. Foreign biomass that has entered the country can be used as fuel, e.g. wood pellets. Nevertheless, some products, such as ethanol or some forest industry byproducts, can be used for both energy and raw material purposes, which make it necessary to know where the products are consumed. Biomass is also traded for biofuels production, and in the future this will be a more common trend when large bio-refineries produce liquid biofuels for the road transport sector. Eventually, most of the products that include biomass end up in recycling and energy production.

\subsection{International trading of biomass}

Ethanol, vegetable oils, fuel wood, charcoal and wood pellets are the most important products that currently are internationally traded for energy purposes. Nevertheless, the international trade of these products is much smaller than the international trade of biomass for other purposes. Table III depicts the volumes of global production and international trade of various biomass products. Most of the reviewed biomass products are mainly consumed locally in the countries where they were produced, but in the case of products such as sawn timber, paper and paperboard, palm oil and wood pellets, remarkable shares of the total production are exported.

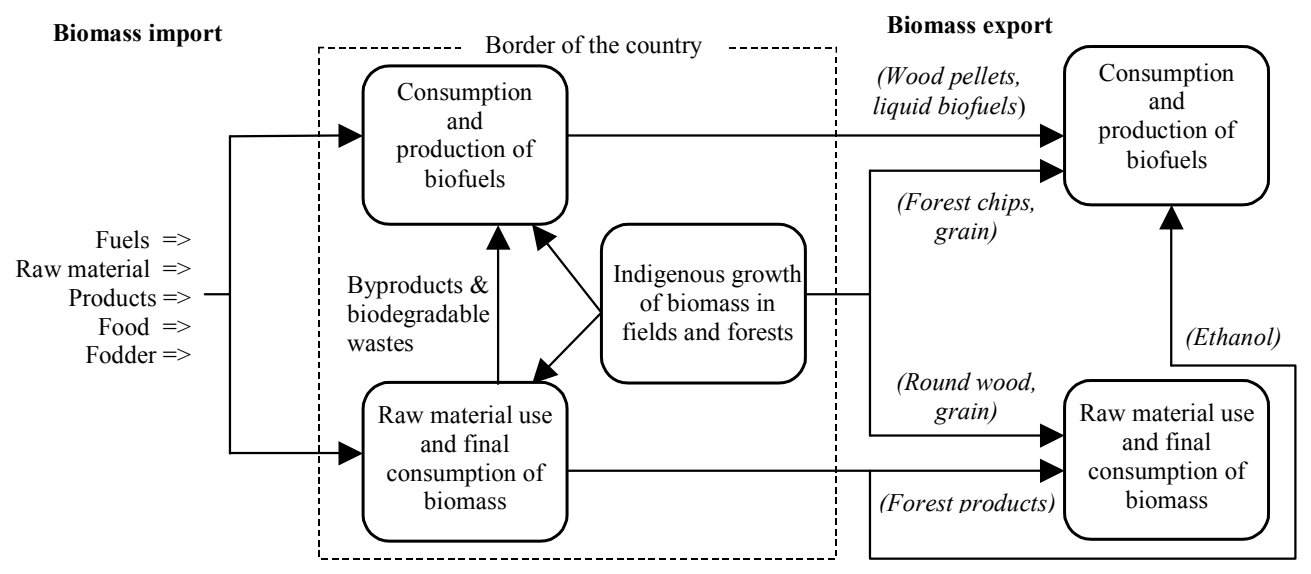

Figure 1: An illustration of biomass streams within a country and between countries. Products presented in brackets represent examples of products [10]

Table III: An overview of world biomass production and international trade in 2004

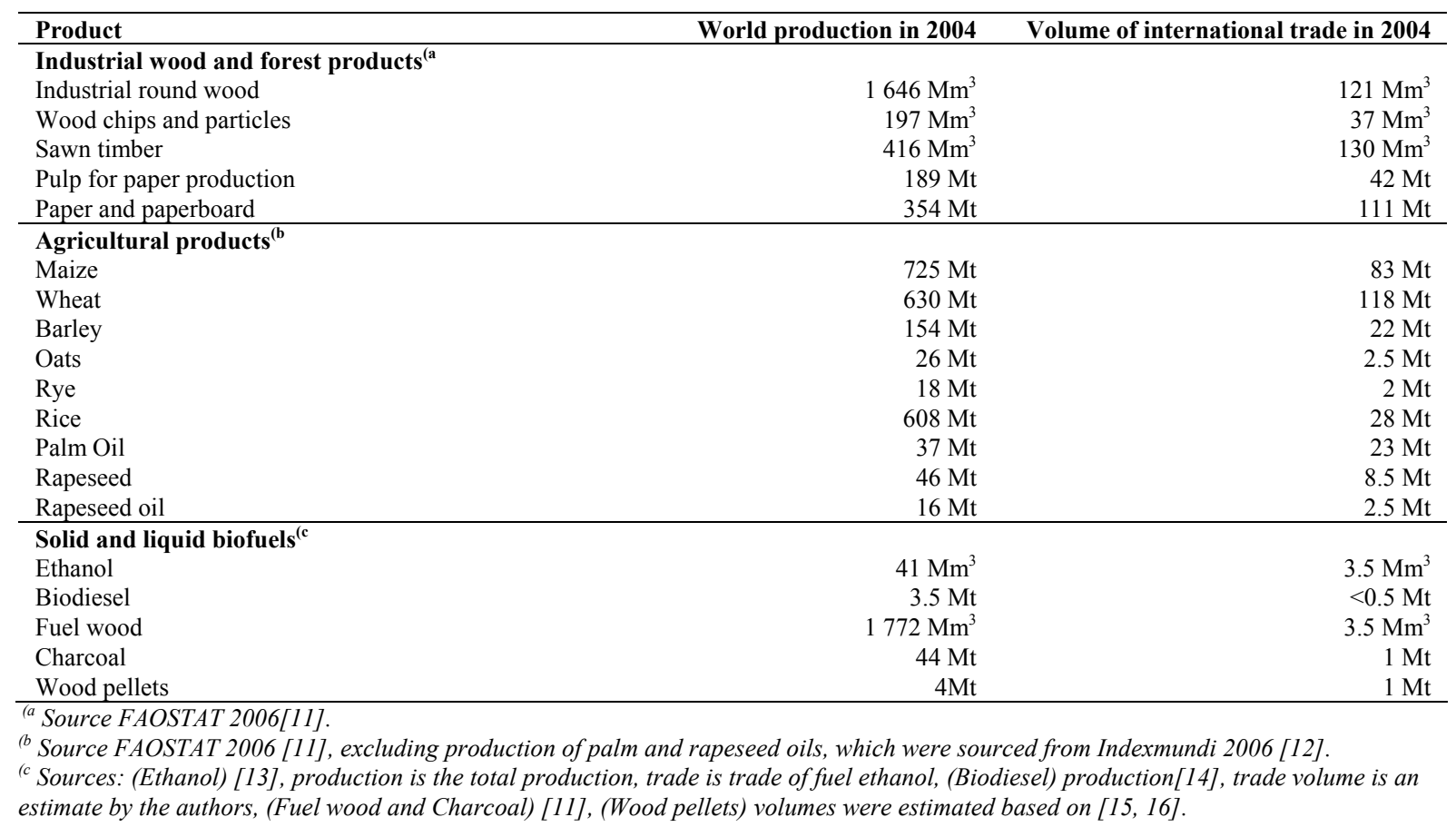


(47 $000 \mathrm{Mt}$ ) and the USA (24 $000 \mathrm{Mt})$ have the largest biomass resources in their forests [18].

The current rate of the utilisation of forest resources varies between world regions. Deforestation, poor forest management and overuse of wood resources are serious problems in several areas, but on the other hand in many parts of the word the sustainable utilisation of forest resources can be increased. Estimates by FAO show that the global production of industrial round wood and wood fuel reached a total of $3350 \mathrm{Mm}^{3}$ in 2000 [18]. As much as $53 \%$ of this was wood fuel, and about $90 \%$ of wood fuel is currently produced and consumed in developing countries [1]. In 2004, the total production of industrial round wood was $1643 \mathrm{Mm}^{3}$, the USA $\left(418 \mathrm{Mm}^{3}\right)$, Canada $\left(198 \mathrm{Mm}^{3}\right)$, Russia $\left(130 \mathrm{Mm}^{3}\right)$, Brazil $\left(110 \mathrm{Mm}^{3}\right)$ and China $\left(93 \mathrm{Mm}^{3}\right)$ being the largest producers [19].

Industrial round wood is a rather local product. Over $90 \%$ of the production of industrial round wood is consumed locally in the same countries as it is produced.
However, industrial round wood is one of the most important biomass products in world trade (see Table I), and unprocessed wood has increasingly been shipped to markets away from where it is harvested. The wood import regions are Asia, mainly China and Japan, and the Nordic countries where a part of imported wood is converted into energy. Russia, Eastern Europe, Oceania and North America are the main sources of exports (Figure 2). Over the past 15 years, Russia has become the most important wood exporter. The collapse of the Soviet Union and the transition to a market economy in the beginning of the 1990s badly damaged the Russian forest industry, resulting in a collapse of the demand in Russian internal markets and the production volumes as well as the stagnation of investments in the industry. The Russian forest industry sector has recovered slowly from the economic reform, resulting in increasing export of raw wood. In 2004, wood export from Russia totalled 42 $\mathrm{Mm}^{3}$ (without bark) [19].

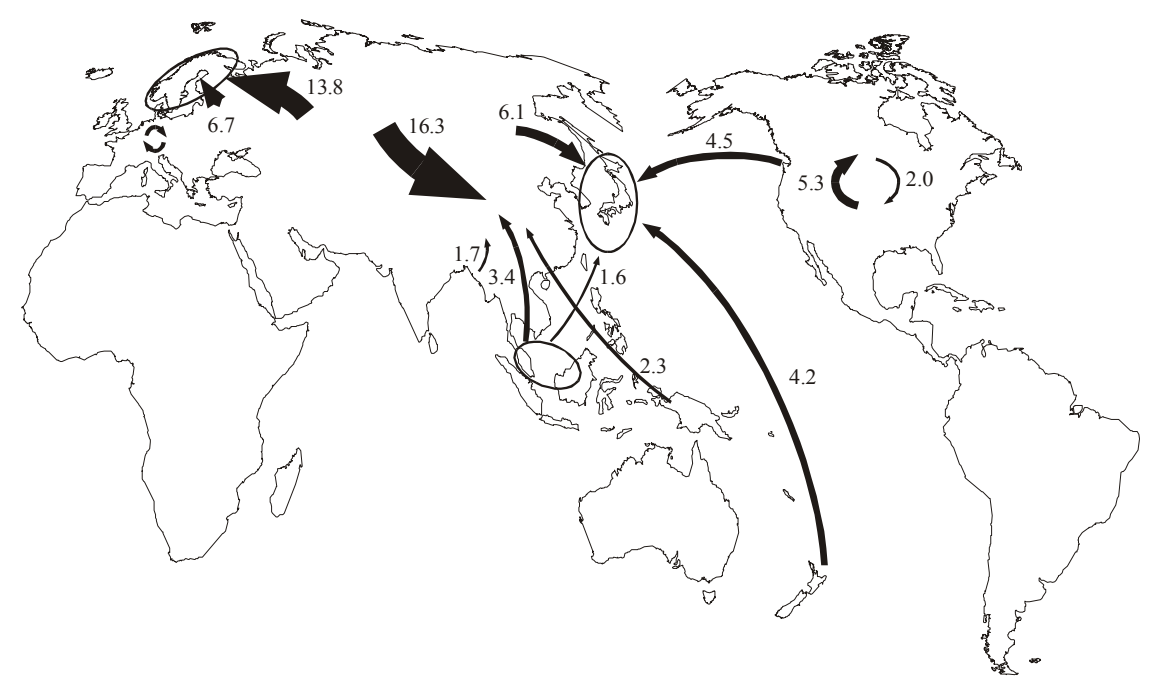

Figure 2: Main global trade streams of industrial round wood, $\left(\mathrm{Mm}^{3}\right)$ in 2004. The total trade volume of industrial round wood was $121 \mathrm{Mm}^{3}$. Figures are without bark and includes wood chips. Data obtained from [19].

\subsection{Wood pellets}

Wood pellets are rapidly becoming a successful traded biomass commodity. Wood pellets offer a number of advantages compared to unrefined biomass: they generally have a low moisture content and a relatively high heating value (about $17 \mathrm{MJ} / \mathrm{kg}$ ), which allows longdistance transport by ship without affecting the energy balance. Handling during transport is relatively easy, and they can be stored over long periods without significant loss of dry matter. Applications of wood pellets vary from small-scale residential heating to large-scale cofiring in coal power plants. Due to the additional costs of making pellets from raw material such as saw dust, pellet prices per MJ are relatively high. On the other hand, policy support measures for the production of renewable electricity in various European countries and rising heating oil prices have enabled wood pellets to successfully compete with fossil fuels. These attractive properties have caused the demand for wood pellets to soar upwards over the past years.

In 2004, the majority of global wood pellet production (and consumption) took place in Europe. We estimate that in 2004 up to 2 million tons of wood pellets were produced in Europe (see Table V).

Table V: Estimate on global wood pellet production in 2004.

\begin{tabular}{|c|c|}
\hline Country & ktons \\
\hline Sweden ${ }^{(a}$ & 900 \\
\hline Canada ${ }^{(b}$ & 725 \\
\hline $\mathrm{USA}^{\mathrm{b}}$ & 550 \\
\hline Austria $^{(a}$ & 330 \\
\hline Estonia $^{(a}$ & 200 \\
\hline Finland ${ }^{(a}$ & 190 \\
\hline Denmark $^{(\mathrm{a}}$ & 190 \\
\hline Italy ${ }^{(a}$ & 170 \\
\hline Poland ${ }^{(a}$ & 120 \\
\hline Germany ${ }^{(a}$ & 120 \\
\hline Norway ${ }^{(a}$ & 50 \\
\hline Rest world & 455 \\
\hline In total & 4000 \\
\hline
\end{tabular}


The most important pellet producer is Sweden. The raw materials for pellets are byproducts of the mechanical wood processing industry. The total domestic consumption typically exceeds production, making the import of pellets necessary. Other important producers are Canada, the USA, Austria, Finland, the Baltic States and Germany. Pellet demand has soared over the past years in amongst others Italy, the Netherlands, Belgium and the UK. This has led to important trade streams.

About 3 Mt of the world's 4 Mt wood pellet production was consumed in Europe in 2004. The consumption of pellets was largest in Sweden (1.3 Mt), Denmark $(0.7 \mathrm{Mt})$, Italy $(0.2 \mathrm{Mt})$, the Netherlands $(0.2$ Mt) and Austria (0.2 Mt). The USA is the most important pellet user in North America (0.9 Mt in 2004) [21].

Given the different availability of and demand for wood pellets, different costs of feedstocks and the immature wood pellet market, production costs and price levels may differ significantly all over the world. These price differences are of course the major driver behind the developing international pellet trade. The main trade streams of wood pellets are depicted in Figure 3.

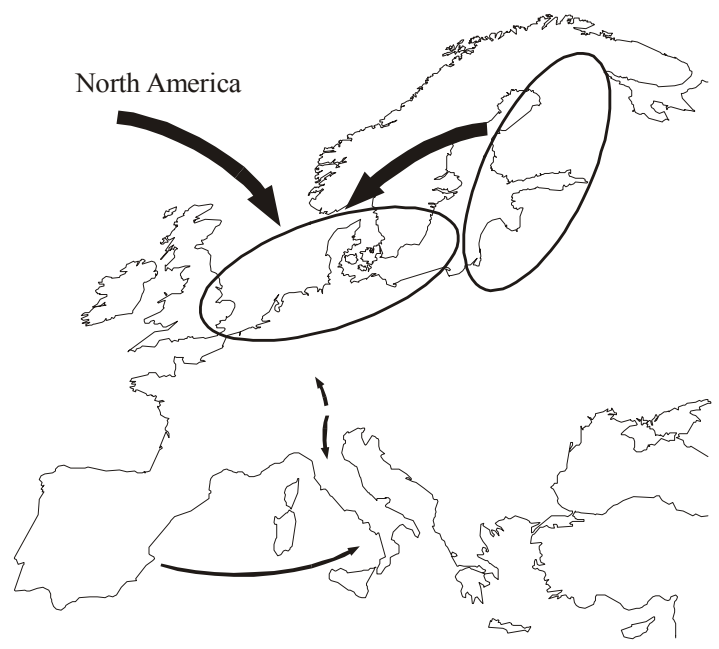

Figure 3: Major international trade streams of wood pellets in 2004. The estimated total trade volume was 1 Mt. Data obtained from [15] and authors' estimates.

North America, especially Canada, is the most important exporting region of wood pellets. The manufacture and export of wood pellets in Canada has grown strongly in the past several years, primarily on the west coast. In 2004, there were at least 11 pellet plants in Canada, almost half in British Columbia (BC) [22]. By the end of 2006, this number had risen to 23, of which 10 on the west coast. Other important pellet exporting countries are the Baltic States, Finland and other EasternEuropean states. The Finnish pellet industry has been founded on exportation, and in 2004, the export of wood pellets was 157000 tonnes, three quarters of its total production. Sweden $(56 \%)$, Denmark $(23 \%)$ and the Netherlands $(20 \%)$ were the main destinations for the exported wood pellets [23].

In 2004, Denmark (0.5 Mt), Sweden (0.35 Mt) and the Netherlands $(0.2 \mathrm{Mt})$ were the largest importing countries of pellets [15].

\subsection{International bio-ethanol trade}

Ethanol is a commodity which (regardless of whether produced form biomass or fossil feedstocks) has been produced and traded globally in significant volumes for decades. The (bio-)ethanol market is well-developed, as is the logistical infrastructure in many countries, see e.g. F.O. Licht, [24].

Currently, about $60 \%$ of ethanol production is based on sugar crops, $30 \%$ on grains, $7 \%$ corresponded to synthetic ethanol, and 3\% was produced from other raw materials [25]. Two countries, Brazil and the USA, dominate ethanol production, covering roughly $70 \%$ of the world's production (Table VI). These countries are also the most important producers and users of bioethanol as transportation fuel.

In Brazil, ethanol production is based on sugar-cane. Worldwide, Brazil is the largest producer of sugar-cane. The production of sugar-cane has risen during the past years on an average nearly $10 \%$ per year. In the USA, over $95 \%$ of ethanol is produced from corn.

Table VI: Estimate on global ethanol production in 2004 [26].

\begin{tabular}{lr}
\hline Country & Million litres \\
Brazil & 15400 \\
USA & 13400 \\
China & 3600 \\
India & 1700 \\
France & 800 \\
Russia & 700 \\
South Africa & 400 \\
United Kindom & 400 \\
Rest of the world & 4600 \\
In total & $\mathbf{4 1 ~ 0 0 0}$ \\
\hline
\end{tabular}

Data about fuel ethanol trade are imprecise due to various potential uses of ethanol (fuel, industrial raw material or beverage use) and also because of the lack of proper codes in international trade statistics.

In ethanol trading, Brazil is the largest exporter, the USA and the EU being correspondingly the largest importers (Figure 4). In 2004, the total trade of ethanol was estimated to be $3-4 \mathrm{Gl}$, with Brazil $(2.4 \mathrm{Gl})$ as the main exporter, and the USA, Japan and the EU as the main importers. 


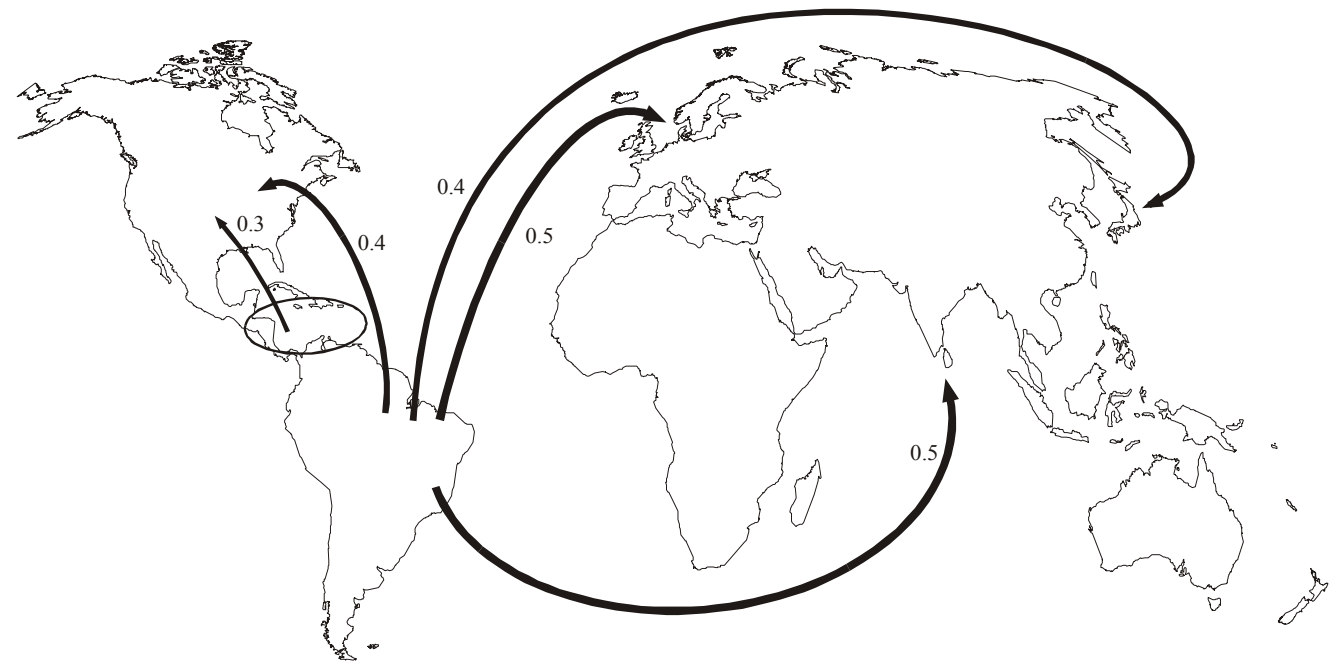

Figure 4: Major ethanol trade streams in 2004, in Gl. The total volume of the trade was estimated to be 3-4 Gl in 2004. Data obtained from $[13,27]$.

\section{DISCUSSION AND CONCLUSIONS}

The trading of solid and liquid biofuels (0.76 PJ in 2004) represents less than $2 \%$ of the total energy use of biomass in the world. Currently, the indirect trade of biofuels through trading of industrial round wood and material byproducts composes the largest share of the trade $(0.54 \mathrm{EJ})$. The remaining part of trading consisted of products that are traded primarily for energy purposes, ethanol (0.09 EJ) and palm oil (0.04 EJ) being the most important commodities. In the future, it can be expected that also increasing amounts of other vegetable oils (e.g. soy bean oil, jatropha oil) and solid biomass streams (wood pellets, but also pellets from agricultural residues) will be traded.

The direct trade of biofuels is growing rapidly, but so far, the volume of indirectly traded biofuels is almost a factor of 2.5 larger than the direct streams. This is a remarkable result, which has gained little attention so far. Methodological issues regarding the indirect import and export of biofuels will need more exploring in order to allow better insights into global biomass carbon flows.

The current volume of international biofuels trade is a long way from its estimated theoretical maximum of 80-150 EJ. Given the current climate policy developments in e.g. the EU and the US, a strong increase in trade can be expected in the near future. However, it should be kept in mind that local use of biomass is often more reasonable than exporting, and for this reason imported biomass will have only a limited proportion in the global energy use of biomass. Nevertheless, the trade development in some sectors, such as in ethanol and wood pellets and vegetable oils, will be rapid over the coming years.

During the work on this paper, it has become clear that high-quality statistics on global bioenergy trade are missing. This impedes charting trade flows, makes the evaluation of policies on trade flows difficult and hampers the market development itself. Keeping more statistics on biomass trade and end-use should therefore be stimulated. Despite the preliminary character of this study, its results can serve as a starting point for annual and continuous monitoring of the development of international biofuels trade.

\section{REFERENCES}

[1] IEA. 2004. World Energy Outlook 2004. ISBN 9264-1081-73. $570 \mathrm{p}$.

[2] Statistics Finland. 2005. Energy Statistics 2004. Official statistics of Finland. Energy 2005:2. Helsinki. 149 p.

[3] REN21 Renewable Energy Policy Network. 2005. Renewables 2005 Global Status Report Worldwatch Institute. Washington, DC. 80 p. Available: http://www.worldwatch.org/brain/media/pdf/pubs/re n21/ren21-2.pdf.

[4] Commission of the European Communities. 2005. Biomass Action Plan, Communication from the Commission, Brussels 7.12.2005. 47 p.

[5] Berndes, G., Hoogwijk, M. \& van den Broek, R. 2003. The contribution of biomass in the future global energy supply: a review of 17 studies. Biomass and Bioenergy. Vol. 23 (2003). pp. 1-28.

[6] Hoogwijk, M. 2004. On the global and regional potential of renewable energy sources. Promoters Turkenburg W.C. and de Vries H.J.M. Copernicus Institute, Utrecht University. ISBN 90-393-3640-7. $256 \mathrm{p}$.

[7] Hoogwijk, M., Faaij, A., Eickhout, B., et al. 2005. Potential of biomass energy out to 2100 , for four IPCC SRES land-use scenarios. Biomass and Bioenergy. Vol. 29 No. 4, October. pp. 225-257.

[8] Smeets, E., Faaij, A. \& Lewandowski, I. 2004. A quickscan of global bio-energy potentials to 2050 . An analysis of the regional availability of biomass resources for export in relation to the underlying factors. Copernicus institute - Utrecht University. 90-393-3909-0. $121 \mathrm{p}$.

[9] Faaij, A. \& Domac, J. 2006. Emerging international bio-energy markets and opportunities for socioeconomic development. Energy for Sustainable Development. Vol. X No. 1, March 2006. pp. 7-19.

[10] Heinimö, J. 2006. Methodological aspects on international biofuels trade: international streams and trade of solid and liquid biofuels in Finland. Submitted to Biomass and Bioenergy on 15 September 2006. 
[11] FAOSTAT data. 2006. Retrieved 21 July 2006 from http://faostat.fao.org/.

[12] Indexmundi. 2006. "Online database - Agricultural Commodities - Production, Consumption, Exports, and Imports". Retrieved 21 July 2006 from http://www.indexmundi.com/en/commodities/agricul tural/.

[13] Rosillo-Calle, F. \& Walter, A. 2006. Global Market for bioethanol: historical trends and future prospects. Energy for Sustainable Development, Volume X No. 1, March 2006. pp. 20-32.

[14] Worldwatch Institute. 2006. Biofuels for Transportation: Global Potential and Implications for Sustainable Agriculture and Energy in the 21st Century, prepared for the German Ministry of Food, Agriculture and Consumer Protection (BMELV) in coordination with the German Agency for Technical Cooperation (GTZ) and the German Agency of Renewable Resources (FNR). Washington, DC. $396 \mathrm{p}$.

[15] Dahl, J., Broechner-Andersen, M., Hanh, B., et al. 2005. Wood pellets - a growing market in Europe. 14th European Biomass Conference, 17-21 October 2005, Paris, France. pp. 1975-1978.

[16] Swaan, J. 2006. North American Wood Pellet Industry Update. Presentation in Bioenergy Days. 24 August 2006. Linköping. Sweden.

[17] Hansson, J. \& Berndes, G. 2006. The prospects for large-scale import of biomass and biofuels into Sweden - a review of critical issues. Energy for sustainable development. Vol. X. No. 1. pp. 82-94.

[18] FAO. 2003. State of the World's Forests -2003. Rome. ISBN 92-5-104865-7. $151 \mathrm{p}$.

[19] FAOSTAT. 2006. "Forestry data". Retrieved November 2006 from http://faostat.fao.org.

[20] Dahl, J., Broechner-Andersen, M., Hannh, B., et al. 2005. Wood pellets - a growing market in Europe. 14th European Biomass Conference, 17-21 October 2005, Paris, France. pp. 1975-1978.

[21] Swaan, J. "Biomass" Responsible, Sustainable, Renewable Energy Option. A presentation In "Maximizing Energy Efficiency and Renewable Energy in British Columbia" conference. Vancouver, B.C. March 22-23, 2006.

[22] Bradley, D. 2006. Canada Biomass-Bioenergy Report. Country report for IEA Bioenergy Task 40.

[23] Heinimö, J. \& Alakangas, E. 2006. Solid and Liquid Biofuels Markets in Finland - a study on international biofuels trade. Lappeenranta University of Technology. Department of Energy and Environmental technology. ISBN 952-214-199-2. 92 p. Available: http://www.doria.fi/lutpub.

[24] F.O. Licht. 2006. Licht's World Ethanol \& Biofuels Report.

[25] Walter, A., Rosillo-Calle, F., Dolzan, P. B., et al. 2007. Market Evaluation: Fuel Ethnol. Taks 40 Sustainable Bioenergy Trade; securing supply and demand. Deliverable 8. State University of Campinas. 74 p. Available: http://www.bioenergytrade.org/.

[26] Earth Policy Institute. 2005. "World Ethanol Production, 2004". Retrieved 12 April 2007 from http://www.earthpolicy.org/Updates/2005/Update49_data.htm.
[27] Walter, A., Rosillo-Calle, F., Dolzan, P. B., et al. 2007. Market Evaluation: Fuel Ethanol. Task 40 Sustainable Bioenergy Trade; securing supply and demand. Deliverable 8. State University of Campinas. 74 p. Available: http://www.bioenergytrade.org/. 